\title{
Organic farms face dilemma over new gene technology
}

San Francisco. Organic farmers in the United States, who provide a small but important market for agricultural biotechnology companies, are divided over whether to accept the use of recombinant-DNA products.

The debate has intensified as the National Organic Standards Board (NOSB), the advisory panel that helps to set standards for US organic farming, prepares to discuss recommendations on how to treat recombinant plants and pesticides.

The NOSB is expected to recommend either a moratorium on the use of recombinant DNA, or a general ban that would still allow companies to apply to use indirecombinant DNA products entirely.

Urgency has been given to the board's deliberations by the fact that three pesticides incorporating genetically engineered bacteria have recently arrived on the market, and several new vegetables, including Calgene's 'vine-ripe' tomato and a virus-resistant squash, are awaiting regulatory approval.

At least one biotechnology company has been vigorously lobbying the board to allow use of its genetically engineered products. Jerry Caulder, chairman of Mycogen Corporation in San Diego, says that his company feels NOSB should give its approval both because of the importance of the market and because rejection could harm the image of biotechnology.

In the United States, organic farmers are generally suspicious of recombinant-DNA technology and its impact on the web of ecological relationships on which their farms rely. The Organic Food Production Association of North America, a trade group, has rejected the use of recombinant-DNA technology, saying that it is incompatible with vidual products. But it could also prohibit

organic philosophy and that there are in any case natural substitutes available.

Others, however, believe that some recombinant products could provide useful tools consistent with their philosophy. These accept that recombinant-DNA technology should be seen as a synthetic process, some of whose products can be used in organic farming provided they pass various tests.

Some of these groups would like to accept Mycogen's products, which are based on genetically engineered killed bacteria toxic to crop-devouring insects. The unaltered bacterium, Bacillus thuringiensis, has been a staple of organic methods, and some growers believe a more powerful version could attract more farmers to organic practices.

But others are concerned that the widespread use of a genetically engineered bacterium could stimulate insect resistance and destroy a powerful tool for organic growers. And, they say, recombinant DNA techniques in general contradict the organic philosophy of seeking balance in the agricultural system, rather than relying on narrow technical solutions.

"We have made significant achievements in terms of how to produce food without chemical alternatives, and I don't think anyone wants to throw that out," says Margaret Clark, a member of the NOSB and organic produce manager for a supermarket near Seattle, Washington.

Some researchers believe that acceptance of some biotechnology products by the organic community would be an important breakthrough. Peggy Lemaux, a cooperative extension specialist for the University of California, Berkeley, says the organic industry could bring a valuable perspective to biotechnology research. Sally Lehrman

\section{New head promises shake-up at USGS}

Washington. Gordon Eaton (right), the director of Columbia University's Lamont-Doherty Earth Observatory in Palisades, New York, has been nominated by President Bill Clinton as the twelfth director of the US Geological Survey (USGS).

Providing he receives a quick confirmation from the Senate, Eaton should be in office by early spring. An Earth scientist specializing in tectonics, the 64-yearold Eaton is a former president of Iowa State University. From 1978 to 1981 he was associate chief geologist at the USGS.

Given recent tensions between the survey's three major programmes - in mapping, geology and water resources Eaton says that one of his first priorities

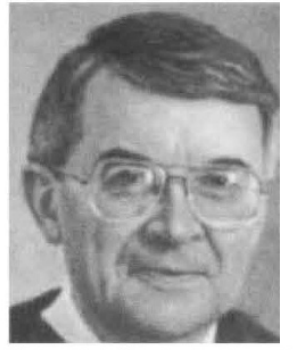

will be to "knock the walls down, and to let people and funds flow across the boundaries between those divisions".

Eaton also stresses that "social relevance is going to have to be a measure of a lot of the work that is done". For example, he says, the survey is likely to expand its research in areas of public interest such as water quality.

The result, he says, could be less emphasis on more traditional research topics such as hard-rock geology. Tony Reichhardt

\section{Indian scientists get larger share of laboratory profits}

New Delhi. Scientists working for India's Council of Scientific and Industrial Research (CSIR) are to receive a share of the profits made by their laboratories from sponsored research projects as an incentive to bring in more contract work from industry.

This follows the government's decision to reduce its support for CSIR. At present the council is required to earn one-third of its budgeted expenses from sources outside the government. Next year this figure may rise to 50 per cent.

The move by the CSIR governing body revives a practice that was abandoned in 1977 after scientists started fighting over their shares. This is not likely to happen again, according to S. K. Joshi, head of the CSIR, because of the guidelines the council has developed for profit-sharing.

Under the new scheme, 40 per cent of profits will be distributed among the principal contributors to the project and 20 per cent among the supporting staff. Five per cent will be put in a welfare fund and the remaining 35 per cent will go to the reserve fund of the laboratory concerned.

CSIR has 40 laboratories. Joshi says the new financial incentives should be strong enough for its scientists to go out and attract industry money for their laboratories. Before the government's introduction of economic liberalization, Indian industry had no alternative but to seek CSIR's help in developing new technologies. But since the removal of curbs on technology imports in 1991, the CSIR has had to face stiff foreign competition.

The profit-sharing scheme was proposed by a committee of senior CSIR scientists to win back Indian industry. In the 1970s, when the incentive scheme was in operation, CSIR laboratories sold 200 technologies each year to industry. This dropped to 25 in the 1980s. "If we must attract our industries we have to give some incentive to our scientists," says Joshi.

The scheme is an extension of a procedure whereby CSIR scientists are already permitted to work as consultants for private or public-sector agencies. They can keep two-thirds of their earnings, up to a maximum of $£ 2,000$ sterling. The rest goes to laboratory reserve funds.

CSIR earned $£ 2$ million through the consultancy activities of its scientists last year, but expects to get more by raising the upper limit of scientists' consultancy fees to $£ 6,000$.

Joshi expects to see some visible increase in funds from industries within a year of the revival of the profit-sharing scheme. Last year, CSIR laboratories spent $£ 80$ million, two-thirds of it on salaries.

K. S. Jayaraman 